\title{
Hemorrhagic intraspinal paragonimiasis
}

Mengmeng Wang, MD, * Yan Ju, MD,* Xueyou Liu, MD, Liang LV, MD, Zeming Wang, MD, and Shu Jiang, MD

Neurology ${ }^{\circledR}$ 2018;90:237-238. doi:10.1212/WNL.0000000000004896

\section{Correspondence}

Dr. Jiang

jiangshuhx123@126.com

Figure 1 Sagittal spine MRI
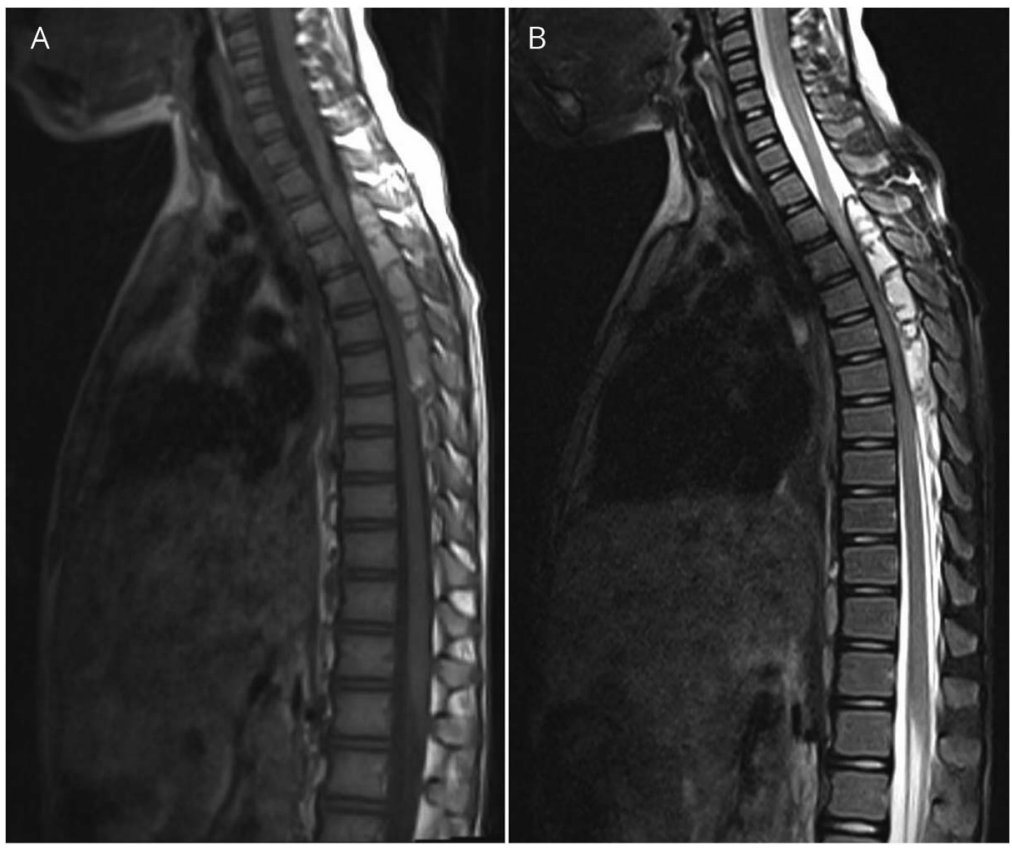

(A) Sagittal T1-weighted and (B) sagittal T2-weighted images show a huge hyperintensity epidural mass at T3-T8 with intralesional septations. The spinal cord is severely compressed.

A 7-year-old girl presented with progressive weakness and paresthesias of both legs for 1 week. Sagittal spinal MRI showed a large epidural hematoma at T3-T8 with intralesional septations (figure 1). On axial images, the mass extended through the left intervertebral foramen to the paravertebral region and was confluent with the thickened left pleura (figure 2). Multiple pulmonary nodules were observed on MRI. The patient had high blood eosinophil count and a positive serologic test for Paragonimusspecific antibody. The patient underwent a complete resection and then was given praziquantel therapy. The symptoms showed progressive improvement. Pathology confirmed the diagnosis of paragonimiasis.

\section{Author contributions}

All authors were involved in clinical care and investigative workup of the patient. Mengmeng Wang and Yan Ju provided pictures of the patient and drafted and revised the manuscript. Xueyou Liu, Liang $\mathrm{Lv}$, and Zeming Wang performed the patient follow-up and drafted and revised the manuscript. Shu Jiang was responsible for the study concept and revised the manuscript for intellectual content.

\section{Study funding}

No targeted funding reported.

\section{Disclosure}

The authors report no disclosures relevant to the manuscript. Go to Neurology.org/ $\mathrm{N}$ for full disclosures.

*These authors contributed equally to this work.

From the Department of Neurosurgery, West China Hospital, Sichuan University, PR China. 

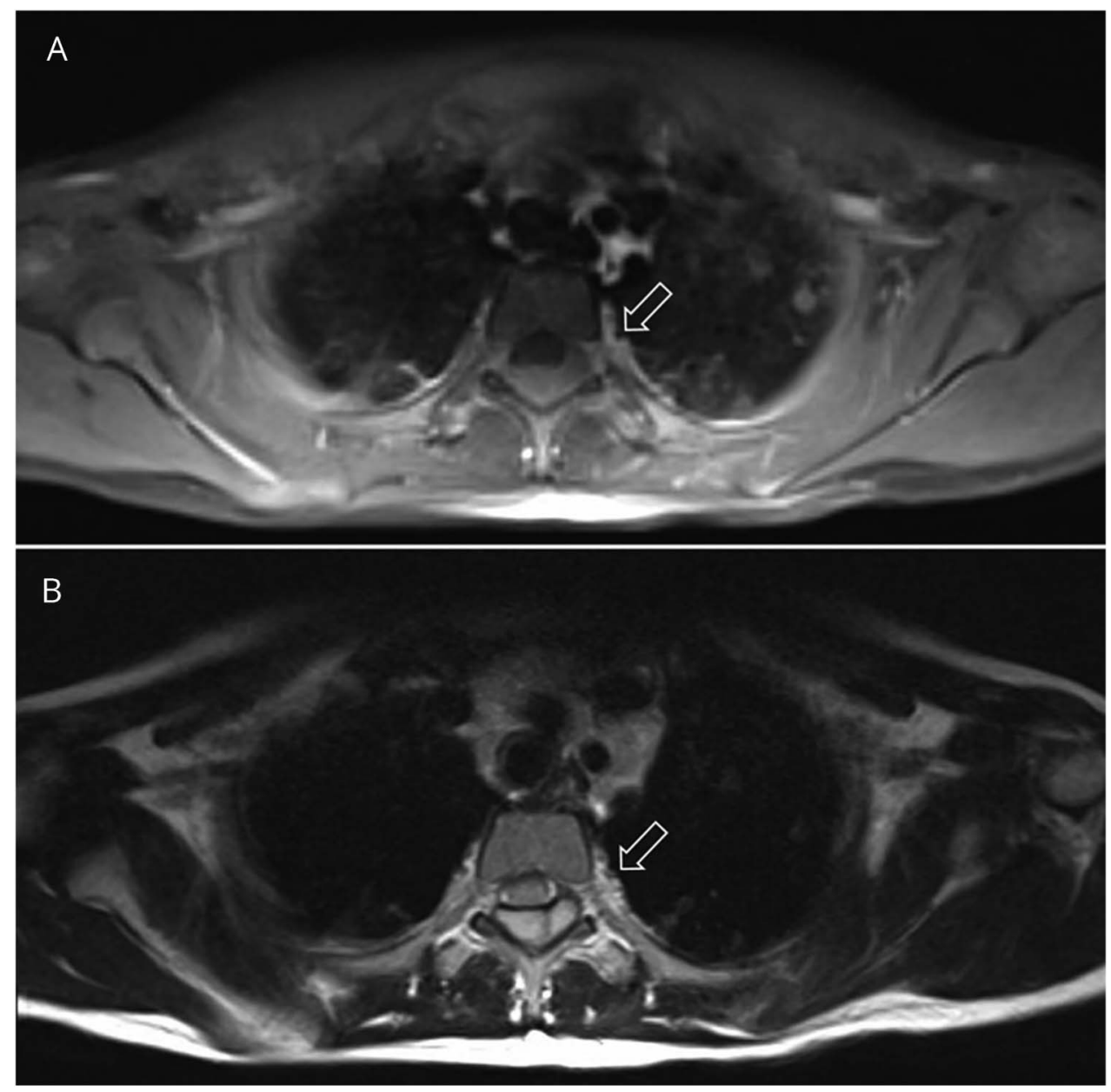

(A) Axial T1-weighted and (B) axial T2 weighted images show a hyperintense dorsal mass. The mass extends through the left intervertebral foramen to the paravertebral region and is confluent with the thickened pleura (white open arrows). Multiple pulmonary nodules can be observed.

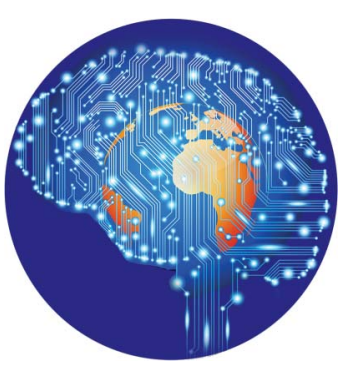

\section{Practice Current: An interactive exchange on controversial topics}

Share your own best practices.

Read commentary with expert opinion.

Explore results on an interactive world map.

NPub.org/NCP/practicecurrent

Neurolog ${ }^{\circledR}$ Clinical Practice 


\section{Neurology}

\section{Hemorrhagic intraspinal paragonimiasis}

Mengmeng Wang, Yan Ju, Xueyou Liu, et al.

Neurology 2018;90;237-238

DOI 10.1212/WNL.0000000000004896

This information is current as of January 29, 2018

\section{Updated Information \&} Services

\section{Subspecialty Collections}

Permissions \& Licensing

Reprints including high resolution figures, can be found at: http://n.neurology.org/content/90/5/237.full

This article, along with others on similar topics, appears in the following collection(s):

\section{MRI}

http://n.neurology.org/cgi/collection/mri

Parasitic infections

http://n.neurology.org/cgi/collection/parasitic_infections

Information about reproducing this article in parts (figures,tables) or in its entirety can be found online at:

http://www.neurology.org/about/about_the_journal\#permissions

Information about ordering reprints can be found online:

http://n.neurology.org/subscribers/advertise

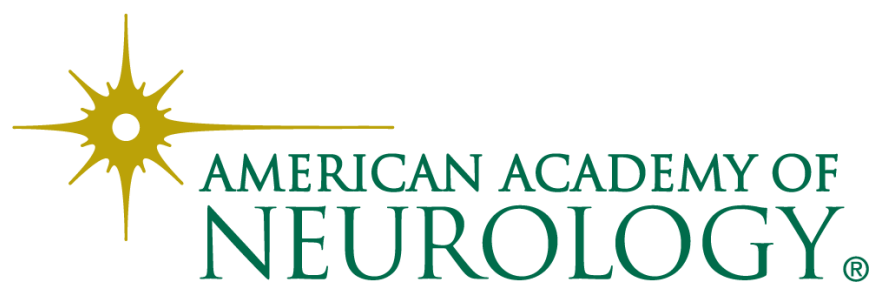

